\title{
Spatial distribution of chili leaf curl disease and its correlation with environmental factors in Southern Irrigated Plain Zone of Pakistan
}

\author{
Abdul Ghani Kandhro ${ }^{1}$, Jamal-U-Ddin Hajano ${ }^{1 *}$, Muhmmad Sabir \\ Bhutto $^{1}$, Muhammad Mithal Jiskani ${ }^{1}$, Agha Mushtaque Ahmed ${ }^{2}$, Fahad \\ Nazir Khoso ${ }^{2}$, Ali Hassan Soomro ${ }^{2}$, Suman Tarique Qazi ${ }^{1}$, Waseem Ali \\ Soomro ${ }^{1}$ and Gulam Hussain Jatoi ${ }^{1}$ \\ 1. Department of Plant Pathology, Faculty of Crop Protection, Sindh Agriculture University, Tandojam 70060- \\ Pakistan \\ 2. Department of Entomology, Faculty of Crop Protection, Sindh Agriculture University, Tandojam70060-Pakistan \\ *Corresponding author'semail: jhajano@sau.edu.pk ; hajanojamal@gmail.com
}

Citation

Abdul Ghani Kandhro, Jamal-U-Ddin Hajano, Muhmmad Sabir Bhutto, Muhammad Mithal Jiskani, Agha Mushtaque Ahmed, Fahad Nazir Khoso, Ali Hassan Soomro, Suman Tarique Qazi, Waseem Ali Soomro and Gulam Hussain Jatoi. Spatial distribution of chili leaf curl disease and its correlation with environmental factors in Southern Irrigated Plain Zone of Pakistan. Pure and Applied Biology. Vol. 9, Issue 4, pp2543-2553. http://dx.doi.org/10.19045/bspab.2020.90270

Received: 20/04/2020 Revised: 01/07/2020

Accepted: 09/07/2020

Online First: 06/08/2020

\section{Abstract}

Chili leaf curl virus (Genus: Begomovirus, Family: Geminiviridae) a whitefly transmitted virus causing chili leaf curl disease (ChiLCD) occurs in Pakistan. Spatial distribution of ChiLCD and its correlation with environmental factors in southern irrigated plain zone of Pakistan was determined. The incidence and severity was recorded based on biological symptoms. There were five repeats for observation at each site; individual repeat comprised ten chili plants. Incidence of the disease was calculated by using mathematical equation, $0-5$ rating scale was used to record the disease severity. Metrological data was collected from nearby regional agro metrological stations. There was significant variation among the disease incidence recorded at different sites of Hyderabad $(\mathrm{df}=9, \mathrm{~F}=13.5, \mathrm{P}=0.0000)$, Tando Allahyar $(\mathrm{df}=9, \mathrm{~F}=1.79, \mathrm{P}=0.1037)$, Mirpur Khas $(\mathrm{df}=6, \mathrm{~F}=1.74, \mathrm{P}=0.1555)$, Jamshoro $(\mathrm{df}=5, \mathrm{~F}=3.81, \mathrm{P}=$ 0.0138), Larkana ( $\mathrm{df}=8, \mathrm{~F}=9.99, \mathrm{P}=0.0000)$ and $\mathrm{Dadu}(\mathrm{df}=9, \mathrm{~F}=3.93,0.0015)$. Severity of the disease was ranging between 1 to 2 -score in the surveyed areas. The minimum and maximum temperature were significantly related with the disease incidence $\left(r^{2}=0.7229, P=0.0458\right.$ and $r^{2}=0.8073, P=0.0218$, respectively) but there was non-significant relation with severity of the disease. Incidence of the disease was negatively correlated with relative humidity $\left(r^{2}=-0.8073, P=0.0218\right)$. There was non-significant negative relationship of the disease severity with relative humidity and rainfall $\left(r^{2}=-0.5774, P=0.1511\right.$, $r^{2}=-0.3515, P=0.3894$, respectively). Rainfall was also negatively non-significantly correlated with the disease incidence.

Keywords: Chili; Leaf curl disease; Relative humidity and rainfall; Temperature 


\section{Introduction}

Chili (Capsicum annuum L.) is economically-important cash crop of Pakistan. Chili is originated from Mexico more than 8,000 years ago, and their domestication and cultivation for the first time in Meso-America occurred approximately 6,000 years ago [1]. It is commonly grown in several subtropical and tropical countries areas of Europe and Asia and is used in both food and medicine. In Pakistan it is grown in different agro ecological regions during summer and winter seasons [2].

Chili is a versatile crop in which fruits are harvested at either the mature green or red stage of maturity. It is also commonly called as red pepper. Chili is also high consumed in tropical and subtropical areas due to its nutritional value and considered as cash crop for farmers and in developed and developing countries [3]. The chili prefers warm humid climate soils, which are basically light and wall drained are best suited. Transplanting has to be done when the plant reaches the height of 15 to $20 \mathrm{~cm}$. it is always done in to pair. Maintaining spacing between rows is essential. Weed free conditions should be maintained. Irrigation must be provided every for up to 15 days after transplanting. The crop maturation period is about 150-180 days which is dependent on variety, climate, fertility and water management. The growth of chili consists of vegetative and reproductive phases. Vegetative phase in chili extends to 75-85 days followed by 7595 days of reproductive phase [4]. Approximately $23.3 \%$ GDP of Pakistan is supported by agriculture sector and becomes largest source of the economy. In Pakistan different ecological conditions are found based on physiographic, climatic, soil type and agricultural land as Indus delta, southern irrigated plain, sandy desert, northern irrigated plain, barani (rainfall), wet mountains, northern dry mountains, western dry mountains, dry western plateau and Sulaiman piedmont [5]. District Thatta, some parts of District Badin and Hyderabad comprise Indus delta zone. Whereas, lower Indus Basin comprise southern irrigated plain zone. Various district of Sindh province are included in this region like Nawabshah, Sanghar, Tharparkar, Badin, districts of upper Sindh including Dadu, Khairpur, Shikarpur, Larkana, Jaccobabad and Sukhur [5].

The various reasons for reduction in yield of chili are mentioned such as insect pests includes aphids, mites and thrips etc and pathogens that includes fungi, viruses, bacteria and nematodes. Chili crop is shown to be attacked by about 35 viruses throughout the world. Majority of these viruses is transmitted through aphid insect vectors, whereas nematodes, thrips, leafhoppers, whiteflies, beetles and fungi involved to transmit the remaining viruses of chili crop. Contact transmission and through soil is also known but the underlying mechanism is unclear yet. Most chili viruses are distributed worldwide with the exception of Chili veinal mottle virus, pepper severe mosaic virus, pepper veinal mottle virus, pepper mild mosaic virus and pepper mottle virus. These have been reported only in certain geographic areas. Many of these viruses cause considerable yield losses [6]. In Pakistan, 7 viruses such as cucumber mosaic virus (CMV), chili veinal mottle virus (CVMV), potato virus Y (PVY), potato virus X (PVX), tobacco mosaic virus (TMV), pepper virus etch (PTV) and pepper mild mottle virus (PMMV) are shown to infect chili in Sindh and Punjab (Hameed, 1995). Chili leaf curl virus (Genus: Begomovirus, Family: Geminiviridae) a whitefly transmitted virus causing chili leaf curl disease (ChiLCD) which is also distributed throughout the world [7-9]. ChiLCD is the most destructive disease in terms of incidence and yield loss. In severe cases, 100 percent losses of 
marketable fruit have been reported $[10,11]$. The typical symptoms consisting of leaf curling, rolling and puckering; blistering of intravenous areas, thickening and swelling of the veins, shortening of internodes and petioles, crowding of leaves and stunting of the whole plant [12].

The most effective method of viral disease management is the use of disease resistant plant varieties. For such purpose different chili varieties have been screened against the leaf curl virus in greenhouse to examine most tolerant variety for recommending farmers [13-15]. However, there is no any baseline work conducted in recent to assess high disease risk points for such screening and its correlation with environmental conditions is also not known during current decade. Thus, this study is planned to determine spatial distribution of ChiLCD and its correlation with environmental conditions in Indus delta and southern irrigated plain zone of Pakistan.

\section{Materials and methods}

\section{The disease assessment}

Visually assessment method was used to record intensity of the ChiLCD under natural conditions at commercial farmer fields in various districts of Sindh province viz., Larkana, Dadu, Mirpurkhas, Tando Allahyar, Hyderabad and Jamshoro. Fields were selected randomly with the keenness of growers for the survey to cover the main arable areas which were managed by growers. There were five repeats for observations at each site, individual repeat was comprising ten chili plants. Incidence of the disease was calculated by following mathematical equation;

\section{Incidence $(\%)=\underline{\text { No. of symptomatic plants }} \times 100$} Total Number of plants under observation

Disease severity was measured by using 0-5 rating scale previously described by [10].

\section{Metrological data}

Metrological data was collected from nearby regional agro metrological stations.

\section{Statistical analysis}

Data collected on the disease intensity measured as disease incidence was processed in analytical software (STATISTIX v. 8.1) for calculating least significant differences among the surveyed locations of individual district. Relationship among the disease intensity and environmental conditions was determined using PRISM v. 5.01 (Graph Pad Software).

\section{Results}

Incidence of chili leaf curl disease in different regions of Sindh

Maximum $100 \%$ incidence of chili leaf curl disease at Hyderabad district was recorded in the fields at Baldiya town, Muhammad Ali Magsi-Farm and Badin road followed by Hyderbad New City (96\%) and Allam KhanFarm (90 \%) (Fig. 1). Minimum $72 \%$ incidence of the disease was recorded at Village Budau Sail-2 followed by Village Budau Sail-1 (74 \%), Nazir Khan Magsi Farm and Village Narija (80 \%) and Abdul Razaque-Farm (82 \%) fields of district Hyderabad (Fig. 1). In district Tando Allahyar maximum incidence of the disease was observed at Kohli Village (96\%) and Hasseb-Farm (94\%) followed by Nawab Kohli (90 \%), Shabeer Shah Rashdi-Farm and Zafarullah-Farm (86\%), Rashdi Farm-2, Village Peer Kathi, and Khuwaja stop (84 \%) (Fig. 2). Whereas Rashdi Farm-1 showed minimum $(78 \%$ ) disease incidence followed by Bashir Magsi-Farm (80 \%) in the same district (Fig. 2). Village Khumbri field at district Mirpur Khas showed significantly higher disease incidence $92 \%$ followed by Dolat Kohli-Farm and Abdul Hammed Solangi-Farm (82 \%) (Fig. 3). Minimum disease incidence in district Mirpur Khas was observed at Village Dudo (72\%) followed by Abdul Jabbar Khaskheli-Farm, Village Machi Goth and Hamidullah Solangi-Farm (74 \%) (Fig. 3). In district Jamshoro, $100 \%$ incidence of the disease was recorded at Village Nawab Chohan and Allah Warayo 
Khoso-Farm (Fig. 4). Field at Village Sikandar Chohan in Jamshoro showed $92 \%$ incidence of the disease which was higher than Near Kotri Junction (90 \%), Saleem Khoso-Farm and Lal Bux-Farm (86 \%) (Fig. 4). In district Larkana nine fields were surveyed for recording the disease. Significantly higher disease incidence $76 \%$ was observed at field of Mukhtair Unar-Farm followed by Village Traghar (64\%) (Fig. 5). Whereas minimum incidence of chili leaf curl disease was observed at Fahad Ali Junejo-Farm (20\%) followed by Liaquat Ali Merani-Farm (32\%), Village Hassan Wahan (42\%) (Fig. 5). Ali Bhutto-Farm showed 60 $\%$ disease incidence, which was higher than Naodaro (58 \%), Banguldaro (56 \%) and Irfan Ali Soomro-Farm (46\%) (Fig. 5). In Dadu district ten fields were surveyed, significantly maximum incidence of chili leaf curl disease was recorded at Hassan Junejo-Farm (58 \%) followed by Ghulam Nabi-Farm (52\%), Foji Jamali-Farm (50 \%), Ali Raza Junejo-Farm (44\%), Shaman Ali Junejo-Farm (42 \%) and Sultan Ali JunejoFarm (40\%) (Fig. 6). Whereas significantly lower disease incidence was recorded at Kakar $(20 \%)$ followed by Dawod JamalFarm (28\%), Village Dur Muhammad and Village Khanpur (34\%) (Fig. 6).

Severity of chili leaf curl disease in different regions of Sindh

There was remarkable variation among leaf curl severity score in chili recorded at different locations of Hyderabad. Maximum disease severity 2-score was recorded at fields located nearby Baldiya town, Muhammad Ali Magsi-Farm, Hyderabd New City and Badin road (Fig. 7). Whereas, severity 1-score was recorded at other remaining fields Such as, Abdul Razaque-
Farm, Allam Khan-Farm, Nazir Khan MagsiFarm, Village Budau Sail-1, Village Narija and Budau Sail-2 of district Hyderabad (Fig. 7). In district Tando Allahyar, maximum disease severity 2-score was recorded at Rashdi Farm-1, Haseeb-Farm, Kohli Village and Nawab Kohli-Farm (Fig. 8). Minimum severity 1-score was recorded at Shabeer Shah Rashdi-Farm, Rashdi Farm-2, Village Peer Kathi, Bashir Magsi-Farm, Khuwaja stop and Zafarullah-Farm locations of Tando Allahyar districts (Fig. 8). Seven fields namely Dolat Kohli-Farm, Village Dudo, Village Khumbri, Abdul Jabbar KhaskheliFarm, Village Machi Goth, Abdul Hameed Solangi-Farm and Hamidullah Solangi-Farm at district Mirpur Khas were surveyed to record the severity of chili leaf curl disease, all the fields showed severity 1-score (Fig. 9). Maximum severity 2-score was recorded at Village Nawab Chohan, Allah Warayo Chohan, Lal Bux-Farm and Near Kotri Junction fields of district Jamshoro (Fig. 10). Whereas, fields located at Village Sikandar Chohan and Saleem Khoso-Farm of district Jamshoro showed severity under 1-score (Fig. 10). In district Larkana the severity of chili leaf curl disease was surveyed at fields of Village Hassan Wahan, Liaquat Ali Merani-Farm, Fahad Ali Junejo-Farm, Village Traghar, Mukhtair Unar-Farm, Banguldaro, Irfan Ali Soomro-Farm, Naodaro, Ali Bhutto-2, the severity 1-score was Recorded at all the surveyed fields (Fig. 11). Similarly, severity 1 -score was recorded at Village Dur Muhammad, Shaman Ali Junejo-Farm, Village Khanpur, Sultan Ali Junejo-Farm, Ali Raza Junejo-Farm, Kakar, Ghulam Nabi-Farm, Foji Jamali-Farm, Dawod Jamali-Farm and Hassan JunejoFarm fields of district Dadu (Fig. 12). 


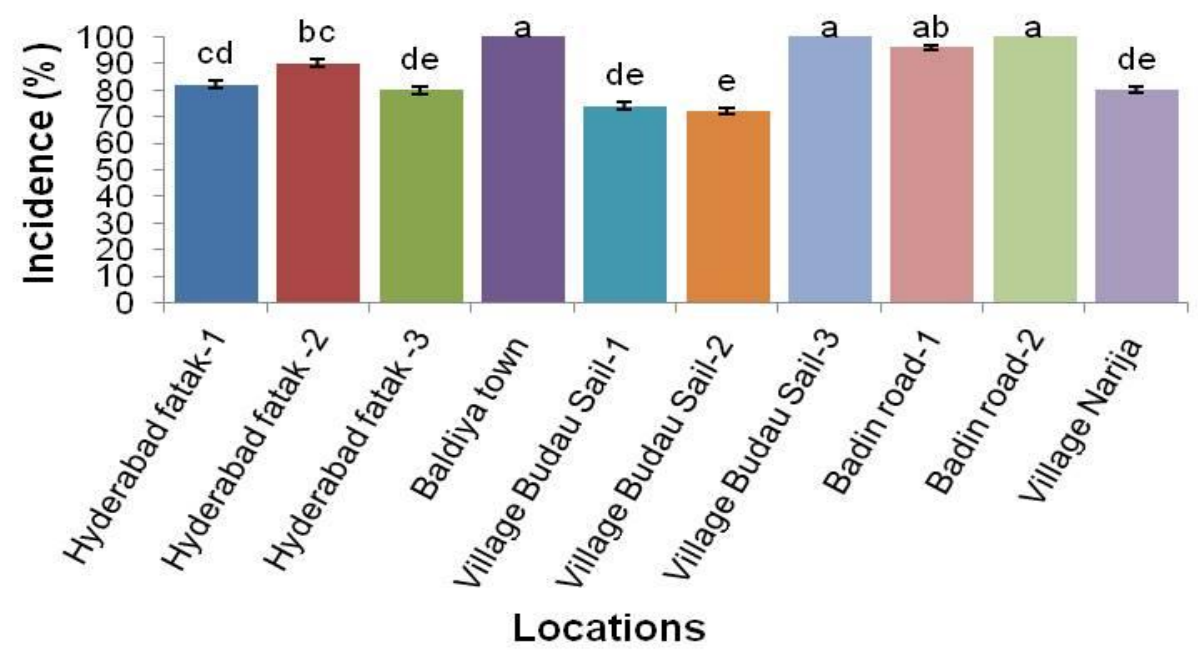

Figure 1. The incidence of chili leaf curl disease at different locations of district Hyderabad

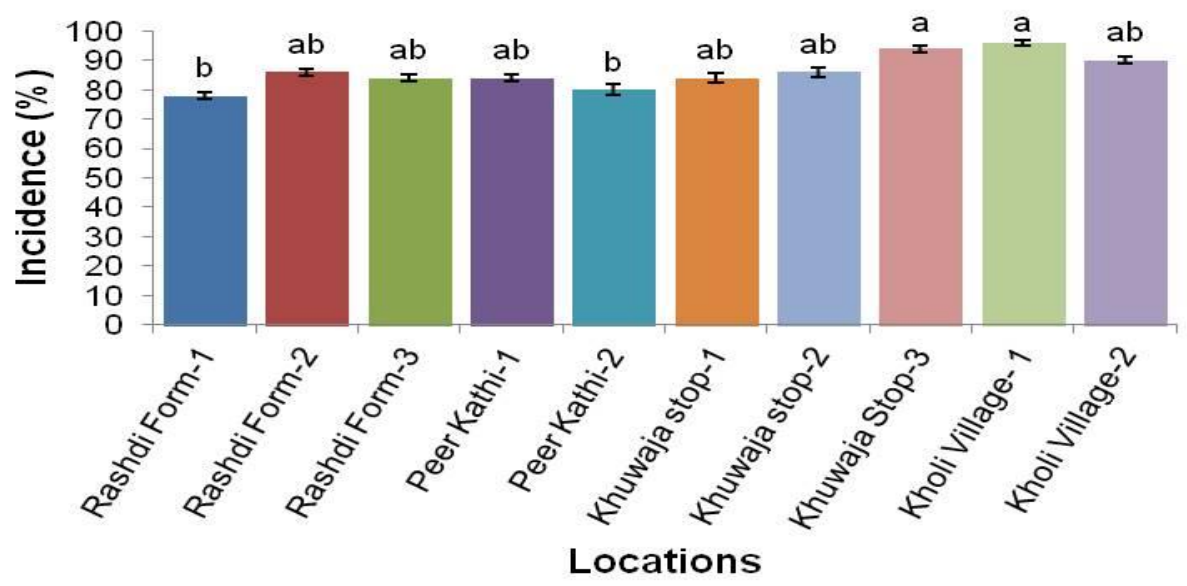

Figure 2. The incidence of chili leaf curl disease at different locations of district Tando Allahyar

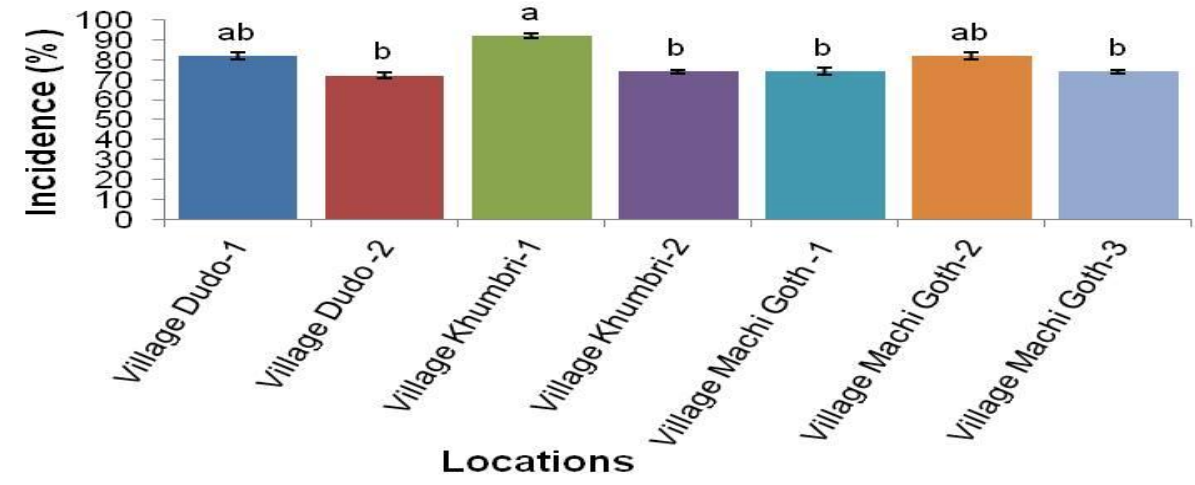

Figure 3. The incidence of chili leaf curl disease at different locations of district Mirpur Khas 


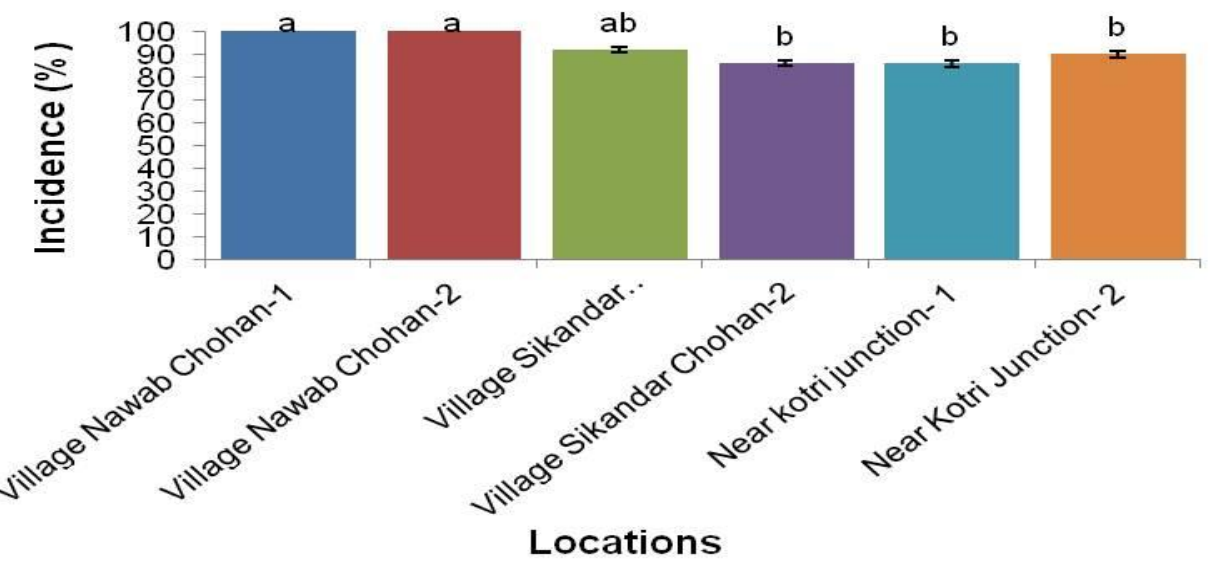

Figure 4. The incidence of chili leaf curl disease at different locations of district Jamshoro

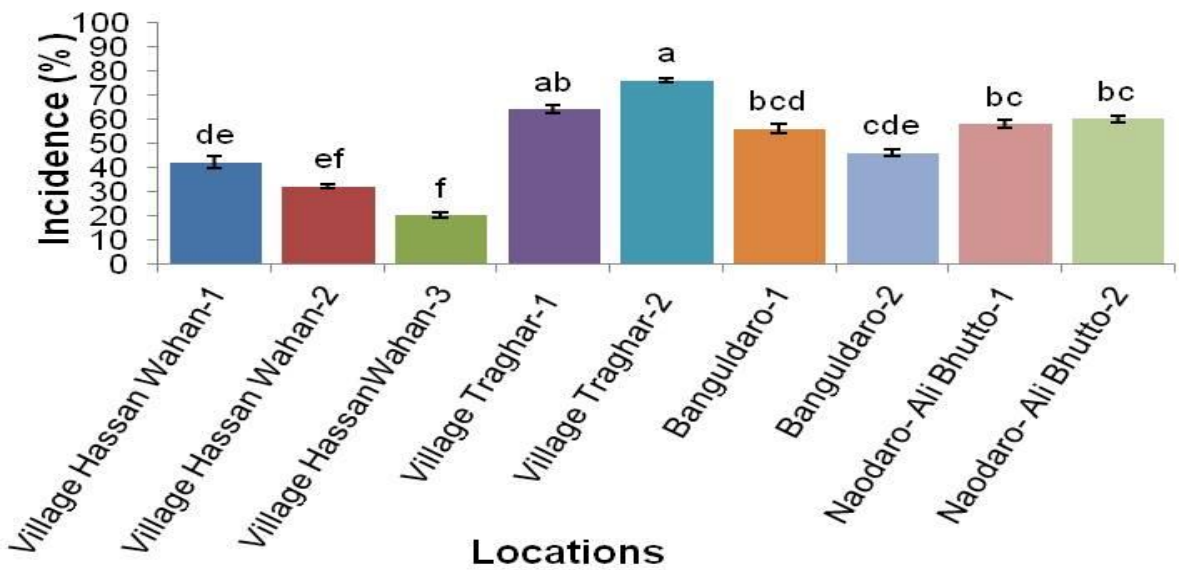

Figure 5. The incidence of chili leaf curl disease at different locations of district Larkana

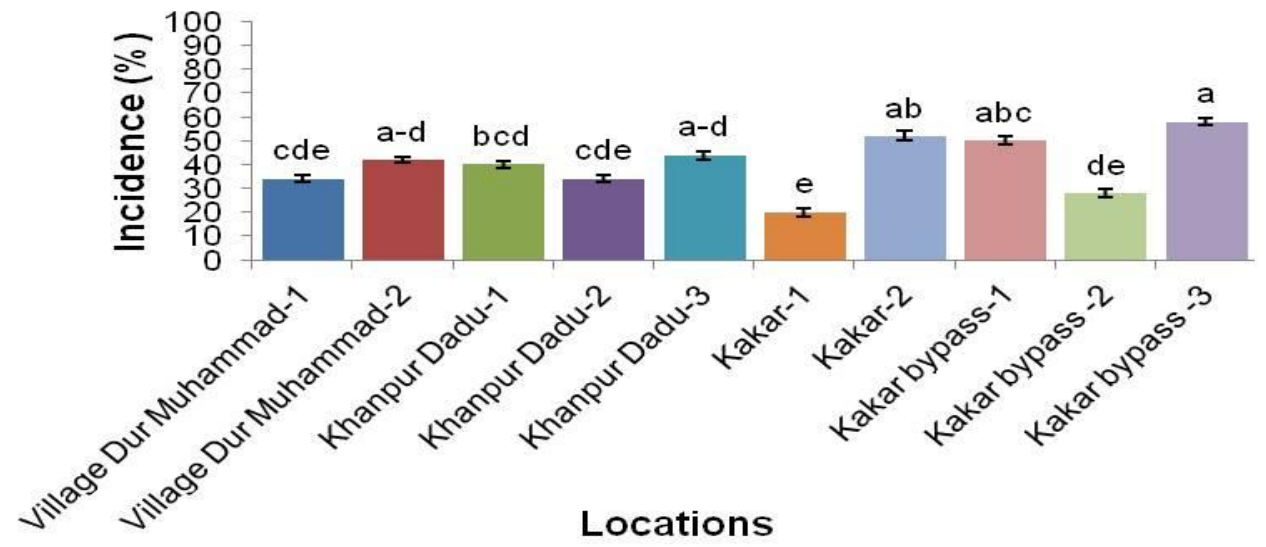

Figure 6. The incidence of chili leaf curl disease at different locations of district Dadu 


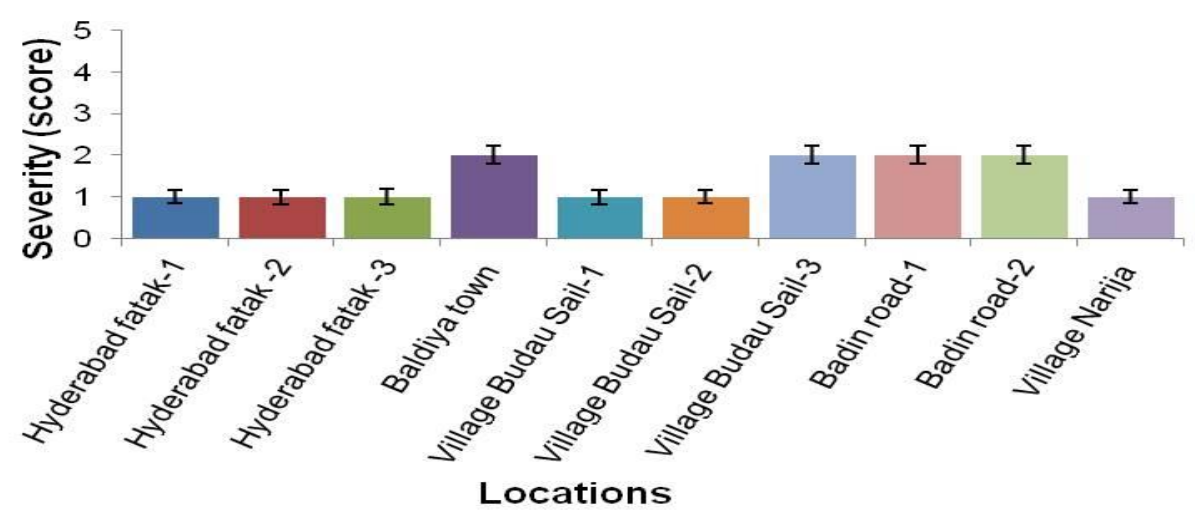

Figure 7. The severity of chili leaf curl disease at different locations of district Hyderabad

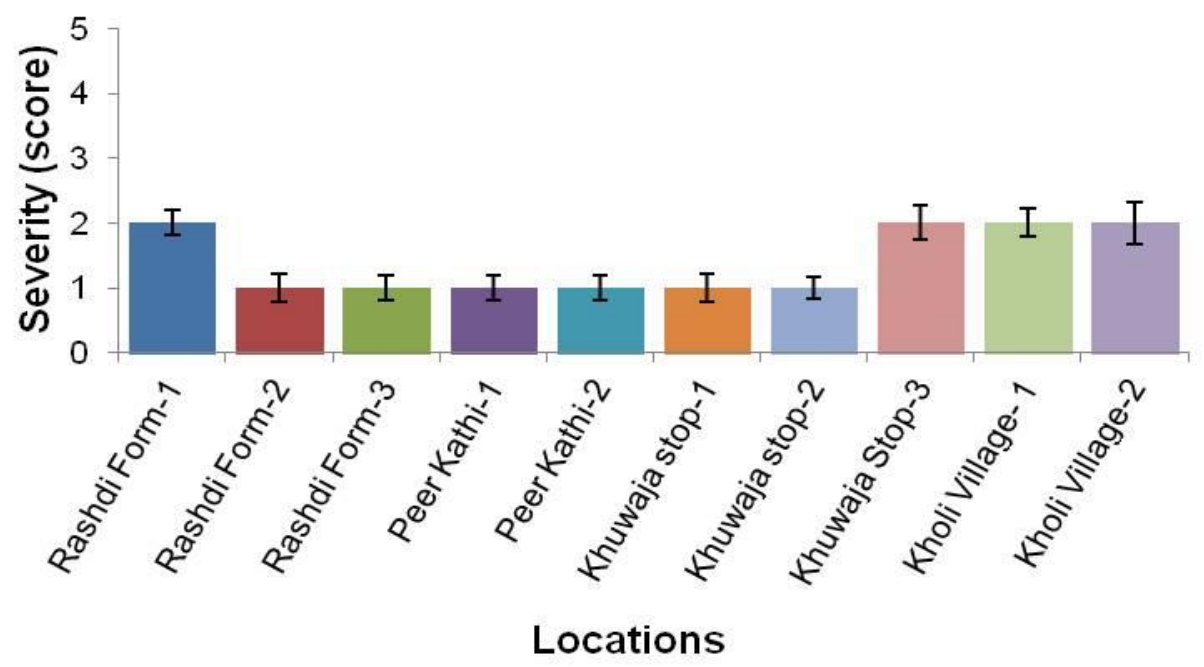

Figure 8. The severity of chili leaf curl disease at different locations of district Tando Allahyar

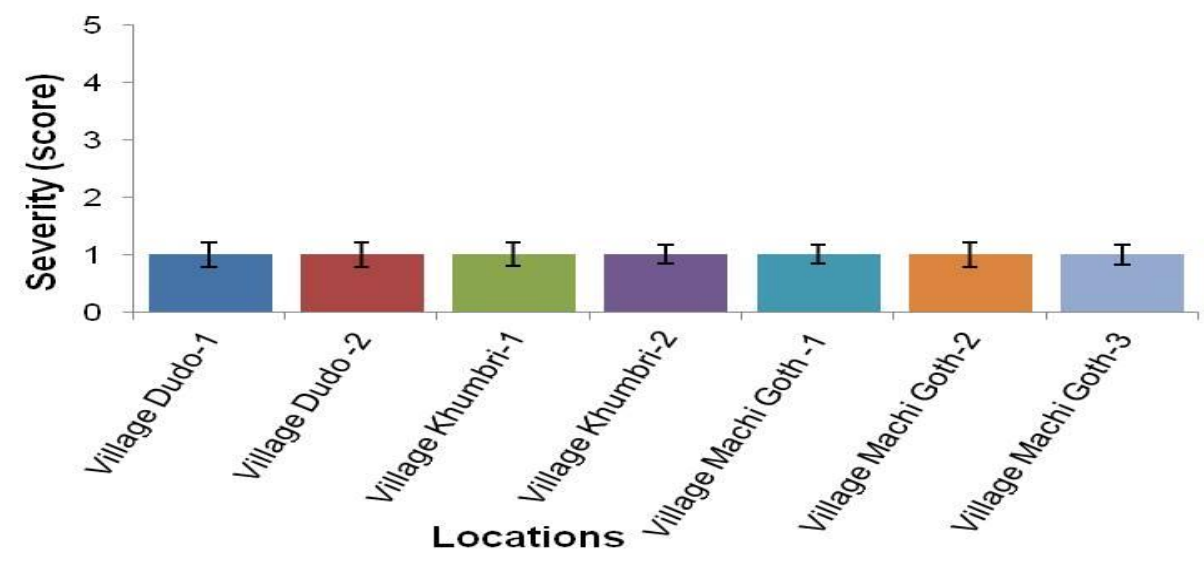

Figure 9. The severity of chili leaf curl disease at different locations of district Mirpur Khas 


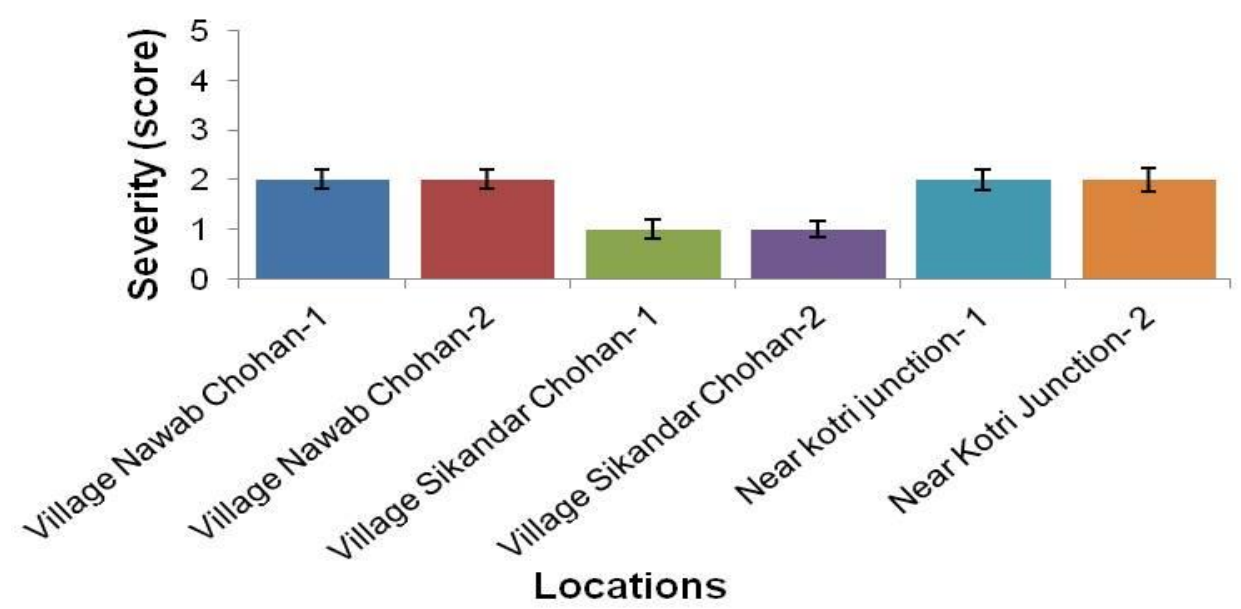

Figure 10. The severity of chili leaf curl disease at different locations of district Jamshoro

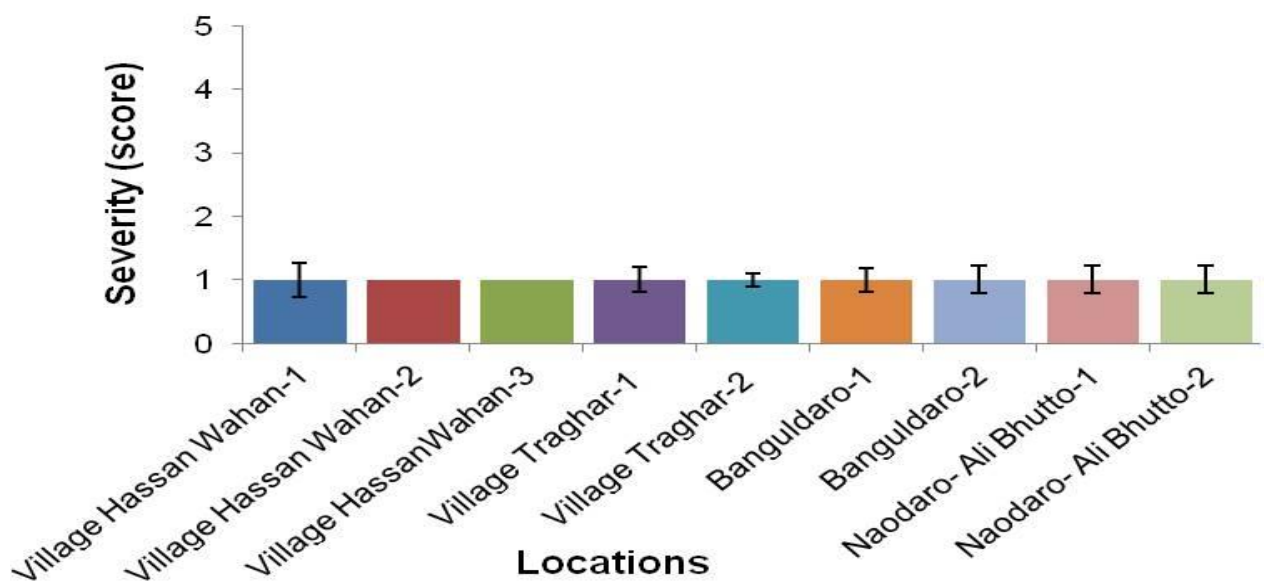

Figure 11. The severity of chili leaf curl disease at different locations of district Larkana

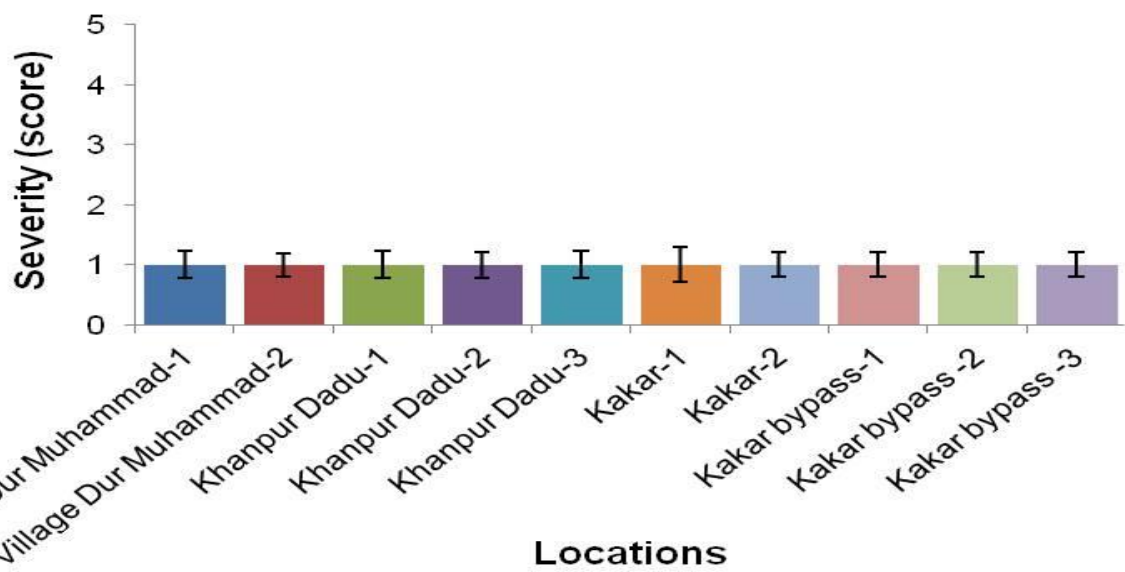

Figure 12. The severity of chili leaf curl disease at different locations of district Dadu 


\section{Relationship of chili leaf curl disease intensity and environmental factors}

Relationship of chili leaf curl disease intensity with environmental factors such as minimum and maximum temperature $\left({ }^{\circ} \mathrm{C}\right)$, relative humidity (\%) and rainfall was determined. The minimum temperature showed significant relation $\left(r^{2}=0.7229, P=\right.$ $0.0458)$ with the disease incidence $(\%)$, where as it was non-significantly $\left(r^{2}=0.4124\right.$, $P=0.2992)$ related with the disease severity (Table 1). Similarly, the maximum temperature was significantly $\left(r^{2}=0.8073\right.$, $P=0.0218)$ correlated with the disease incidence but non-significantly $\left(r^{2}=0.5774\right.$, $P=0.1511)$ correlated with the disease severity (Table 1). The disease incidence and relative humidity showed significant negative relationship $\left(r^{2}=-0.8073, \quad P=\right.$ 0.0218) (Table 1). There was non-significant negative relationship of the disease severity with relative humidity $\left(r^{2}=-0.5774, P=\right.$ $0.1511)$ and rainfall $\left(r^{2}=-0.3515, P=0.3894\right)$ (Table 1). Whereas rainfall was also negatively non-significant correlated with the disease incidence $\left(r^{2}=-0.2953, P=0.3894\right)$ (Table 1).

Table 1. Relationships of chili leaf curl disease with environmental factors

\begin{tabular}{|c|c|c|c|c|}
\hline \multirow[b]{2}{*}{$\begin{array}{c}\text { Disease } \\
\text { parameters }\end{array}$} & \multicolumn{4}{|c|}{ Environmental factors } \\
\hline & $\begin{array}{c}\text { Minimum } \\
\text { Temperature }\left({ }^{\circ} \mathrm{C}\right)\end{array}$ & $\begin{array}{c}\text { Maximum } \\
\text { Temperature }\left({ }^{\circ} \mathrm{C}\right)\end{array}$ & $\begin{array}{c}\text { Relative humidity } \\
(\%)\end{array}$ & Rainfall \\
\hline \multirow{2}{*}{$\begin{array}{c}\text { Disease } \\
\text { incidence }(\%)\end{array}$} & $r^{2}=0.7229 *$ & $r^{2}=0.8073^{*}$ & $r^{2}=-0.8073^{*}$ & $r^{2}=-0.2953^{\mathrm{ns}}$ \\
\hline & $P=0.0458$ & $P=0.0218$ & $P=0.0218$ & $P=0.4618$ \\
\hline \multirow{2}{*}{ Disease severity } & $r^{2}=0.4124^{\mathrm{ns}}$ & $r^{2}=0.5774^{\mathrm{ns}}$ & $r^{2}=-0.5774^{\mathrm{ns}}$ & $r^{2}=-0.3515^{\mathrm{ns}}$ \\
\hline & $P=0.2992$ & $P=0.1511$ & $P=0.1511$ & $P=0.3894$ \\
\hline
\end{tabular}

\section{Discussion}

This study was conducted to determine spatial distribution of chili leaf curl disease and its vector in southern irrigated plain zone of Pakistan. The disease was recorded in term of incidence and severity based on biological symptoms in different districts viz., Larkana, Dadu, Mirpurkhas, Tando Allahyar, Hyderabad and Jamshoro. Vector population was also scouted. Additionaly impact of environmental factors on the disease development was analysis. There was significant variation among the disease incidence recorded at Hyderabad $(\mathrm{df}=9, \mathrm{~F}=13.5, \mathrm{P}=$ 0.0000), Tando Allahyar $(\mathrm{df}=9, \mathrm{~F}=1.79, \mathrm{P}=$ 0.1037), Mirpur Khas $(\mathrm{df}=6, \mathrm{~F}=1.74, \mathrm{P}=$ 0.1555), Jamshoro ( $\mathrm{df}=5, \mathrm{~F}=3.81, \mathrm{P}=0.0138)$, Larkana $(\mathrm{df}=8, \mathrm{~F}=9.99, \mathrm{P}=0.0000)$ and Dadu $(\mathrm{df}=9, \mathrm{~F}=3.93,0.0015)$. Chili leaf curl disease was ranging $72-100,78-96,72-92,86$ to 100,86 $100,20-76$ and $20-58 \%$ in fields surveyed at Hyderabad, Tando Allahyar, Mirpur Khas Jamshoro, Larkana and Dadu, respectively. Generally all the fields were attacked by the disease but district Larkana and Dadu showed lower incidence as compare to remaining surveyed districts. There was remarkable variation among leaf curl severity score in chili recorded at different surveyed districts such as Hyderabad, Tando Allahyar, Mirpur Khas, Jamshoro, Larkana and Dadu. Severity of the disease was ranging between 1 to 2-score. However, there was unique severity (1-score) at different fields surveyed in district Mirpur Khas, Larkana and Dadu. Relationship of chili leaf curl disease intensity with environmental factors such as minimum and maximum temperature $\left({ }^{\circ} \mathrm{C}\right)$, relative humidity $(\%)$ and rainfall was determined. The minimum and maximum temperature showed significant relation with the disease incidence (\%) but there was nonsignificantly related with the disease severity. The disease incidence and relative humidity showed significant negative relationship. There was non-significant negative relationship of the disease severity with relative humidity and rainfall. Whereas rainfall was also negatively non-significantly correlated with the disease incidence.

Leaf curl or yellowing symptoms, typical of those caused by begomovirus infection, are commonly 
observed in chili and tomato plantings in Pakistan [16]. Chili leaf curl virus associated with different betasatellites has also been reported to infect important vegetables including chili, tomato, and potato in India and Pakistan [17]. The disease is reported with $100 \%$ incidence and severe yield losses in Punjab, Pakistan [18]. Ahmad [19] also reviewed that over last few years ChiLCD is occurring with high incidence. He suggested that monitoring vector population during growing season and its relation to the occurrence of the disease is important to effectively manage the disease either without the use of pesticides or minimal use of pesticides. Chili leaf curl virus is very common and infect to entire plants in the field with variable symptoms. It has been observed to cause high disease incidence with showing the symptoms of leaf curling, puckering and reduced size of leaves, closely set internodes and dwarfing of plants. These symptoms produce witch broom appearance and causes to failure of fruits setting. The fruit sets usually small and deformed [20, 21]. Abaxial curling of the leaves accompanied by puckering, thickening and swelling of the veins were observed by Mishra and Singh [22]. The maximum leaf curl disease was observed in $19^{\text {th }}$ standard week when the whitefly population was highest in the field. The increase or decrease of ChiLCD was found directly correlated with vector population and vector population was determined by environmental factors [21]. Appearance of most prominent symptoms such as vein clearing followed by veinal distortion, swelling of veins and vein lets on dorsal side were reported by Muniyappa and Veeresh [23]. However, Similarly, Aulakh [24] showed incidence of chili leaf curl disease was significantly correlated with temperature and relative humidity and nonsignificant with rainfall.

\section{Conclusion}

This survey based study is showing that chili leaf curling disease is prevailing throughout the region. Incidence of the disease was higher at most locations but maximum severity 2 -score was observed, which indicates 6 to $25 \%$ of plants were showing curling, clearing of leaves and swelling of veins. Minimum and maximum temperature were important epidemiological components for the spread and development of the disease. Relative humidity (\%) showed negative relationship with incidence of the disease.

\section{Authors' contributions}

Conducted experiment and field survey: AG Kandhro, MS Bhutto, AH Soomro \& WA Soomro, Designed experiment: JUD Hajano, MM Jiskani \& AM Ahmed, Analyzed data: FN Khoso \& GH Jatoi, Prepared initial draft of manuscript: AG Kandhro \& ST Qazi.

\section{Acknowledgements}

The authors acknowledge the farmers for their willingness to participate in the survey and Regional Agro Metrological Centre, Agriculture Research Institute, Tandojam Sindh for providing metrological data.

\section{References}

1. Perry L \& Flannery KV (2007). Precolumbian use of chili peppers in the valley of Oaxaca, Mexico. P Natl Acad Sci USA 104(29): 11905-11909.

2. Iqbal S, Ashfaq M, Shah H, Haq MI \& Din A (2012). Prevalence and distribution of Cucumber mosaic cucumovirus (CMV) in major chili growing areas of Pakistan. Pak $J$ Bot 44(5): 1749-1754.

3. Anand $\mathrm{T}$ \& Bhaskaran R (2015). Exploitation of plant products and bio agents for eco-friendly management of chili fruit rot disease. J Plant Prot Res 2(49): 195-203.

4. Milind P \& Sashila K (2012). A hot way leading to healthy stay. Int Res J Pharm 3(6): 21-25.

5. Khan AG (2004). The characterization of the agro ecological context in which FAnGR (Farm Animal Genetic Resources) are found. Nairobi, Kenya: ILRI.

6. Green SK. \& Kin JS (1991). Characteristics aid control of viruses infecting peppers a literature review. AVRDC, Technical Bull 18: 60.

7. Hameed S, Shah H, Ali H \& Khalid S (1995). Prevalence of chili viruses in Pakistan.

8. Hussain M, Iram S, Mansoor S \& Briddon RW (2009). A single species of betasatellite is prevalent in chilli across north central Pakistan and shows phylogeographic segregation. J Phytopathol 157(9): 576-579.

9. Tahir M, Haider MS \& Briddon RW (2010). Chili leaf curl betasatellite is associated with a distinct recombinant begomovirus, Pepper 
leaf curl Lahore virus, in Capsicum in Pakistan. Virus Res 149(1): 109-114.

10. Nigam K, Suhail S, Verma Y, Singh V \& Gupta S (2015). Molecular characterization of begomovirus associated with leaf curl disease in chili. World J Pharm Res 4(3): 1579-1592.

11. Kumar Y, Hallan V \& Zaidi A (2011). Chili leaf curl Palampur virus is a distinct begomovirus species associated with a betasatellite. Plant Pathol 60(6): 1040-1047.

12. Senanayake DM, Varma A \& Mandal BJ (2012). Virus-vector relationships, host range, detection and sequence comparison of chilli leaf curl virus associated with an epidemic of leaf curl disease of chili in Jodhpur. Indian Phytopathol 16(1): 146155.

13. Senanayake DMJB, Jayasinghe JEARM, Shilpi S, Wasala SK \& Mandal B (2013). A new begomovirus-betasatellite complex is associated with chili leaf curl disease in Sri Lanka. Virus Genes 46(1): 128-139.

14. Siddiqui SA, Khalid S \& Ilyas MB (1998). Evaluation of pepper lines against tomato leaf curl virus under controlled conditions. $6^{\text {th }}$ National Conference of Plant Scientists, Oct. 20-22, 1998, Department of Botany, University of Peshawar, pp 54-55.

15. Siddiqui SA, Aulakh MA, Ilyas MB \& Khalid S (1999). Evaluation of pepper lines against tomato leaf curl virus. Pak J Biol Sci 24-25.

16. Siddiqui SA (1999). Determination of pepper as alternate host of tomato leaf curl virus (TLCV) and greenhouse screening of tomato germplasm agonist TLCV. M.Sc (Hons.) Thesis Department Plant Pathology
University Agriculture, Faisalabad, Pakistan.

17. Kumar, S., S. Kumar, M. Singh, A. K. Singh and M. Rai. 2006. Identification of host plant resistance to Pepper leaf curl virus in chili (Capsicum species). Sci HorticAmsterdam 110(4): 359-361.

18. Shih SL, Tsai WS, Green SK, Khalid S, Ahmad I, Rezaian MA \& Smith J (2003). Molecular characterization of tomato and chili leaf curl begomoviruses from Pakistan. Plant Dis 87(2): 200.

19. Iqbal MJ, Hussain W, Zia-Ur-Rehman M, Hameed U \& Haider MS (2016). First report of chilli leaf curl virus and associated alphaand beta-satellite DNAs infecting nettle weed (Urtica dioica) in Pakistan. Plant Dis 100(4): 870.

20. Akhter A, Qazi J, Saeed M \& Mansoor S (2009). A severe leaf curl disease on chilies in Pakistan is associated with multiple begomovirus components. Plant Dis 93(9): 962-962.

21. Ahmad A (2011). Chili leaf curl viral disease in Pakistan; A Hand Book on Epidemiology of Chil CV. Paperback Taschenbuch 1800.

22. Hussain M (2004). First report of tomato leaf curl New Delhi virus affecting on chili pepper in Pakistan. Plant Pathol 53(2): 794800.

23. Navot N, Pichersky E, Zeidan M \& Zamir D (2014). Chili yellow leaf curl virus: a whitefly transmitted geminivirus with a single genomic component. Virol 185(1): 151-161.

24. Mishra AK \& Singh TK (2013). Pathological anatomy of virus infected chili plants. Indian Phytopathol 26(3): 111-114. 